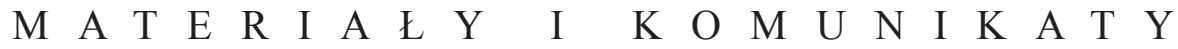 [M A T E R I A L \& A N N O U N C E M E N T S ]
}

WOLFGANG AHRENS

https://doi.org/10.17651/ONOMAST.65.2.18

Onomastica LXV, 2021

wahrens@yorku.ca

ORCID: 0000-0002-8649-1482

York University

Toronto, Canada

SHEILA EMBLETON

embleton@yorku.ca

ORCID: 0000-0001-7245-1845

York University

Toronto, Canada

\section{CONTEMPORARY TRENDS IN NAMES OF WINES AND WINERIES IN THE ENGLISH-SPEAKING WORLD}

Barbara, we raise our glasses to you!

Keyw ords: wine, wineries, wine names, winery names, Niagara

Over ${ }^{1}$ the past several decades, the number of wineries in the province of Ontario, Canada, has grown substantially. There are now some 50 wineries in the Niagara region and about 180 in Southern Ontario. Canada has about 800 wineries overall, becoming a major player in the wine production field. What has caused this growth? First, there has been an undeniable shift in consumer preference from beer and spirits towards wine. Second, there has been an increase in immigration particularly from countries where wine drinking is the norm and from this group of immigrants, there were of course a number who were familiar with the wine making process. Among the immigrants, the Italians were the most prominent, with the Portuguese behind and to a lesser extent (mostly earlier arrivals) Germans and Hungarians. Third, the most prominent reason for the increase

${ }^{1}$ For their comments, we would like to thank members of the audience at the two presentations we have given on this topic: Canadian Society for the Study of Names Annual Meeting, Brock University, St Catharines, Ontario, May 24, 2014; and Annual Conference of the International Linguistic Association, Hofstra University, Hempstead, New York, March 12, 2016. This paper can be seen as an early study in a small corner of the field of commercial naming. In that vein, it has some similarities to Ainiala (2020), which studied 15 kiosk and 84 grill food names in Finland, and interestingly also shows an important role for humour in commercial naming. 
in wineries was a change in Ontario government legislation. After the lifting of Prohibition in 1927, Ontario introduced a moratorium on the issuing of new licenses for setting up wineries. This moratorium was maintained until 1974 with the result that the number of wineries in Ontario was reduced from 1927 to 1974 from 61 to only 6 . After the granting of new licenses, the number of Ontario wineries mushroomed to its present 180 . Fourth, also aiding in this growth was the planting of grape varieties new to the region and familiar to European tastes. Farms in the Niagara region, which had been growing vegetables and fruit, were now gradually converted into more profitable vineyards.

Initially, it was customary to name wineries after the family owning the winery and wines carried the grape variety on their label. However, with the growing number of wineries, newer wineries were attempting to achieve recognition in the crowd and sought this by catching attention through their winery names and the names on their wine labels. Now wineries commonly engage advertising designers to help in the branding and re-branding, and label design, as wineries try to achieve visibility among the large number of competing wineries. Pérez Hernández (2013, p. 34) also observes in Spain that "wine companies are increasingly relying on branding professionals", even if their strategies are not very systematic.

The Niagara region in Canada is treated here as a prime example of this process. However, similar naming system changes can be observed in other regions of Canada, such as British Columbia and other wine growing regions of Ontario. To a lesser extent one can also see the appearance of newer, more colourful brand names for wineries and wines in other English-speaking areas of the world, such as California (USA), Australia, New Zealand and South Africa. To our knowledge, there is almost no published scholarly work on this topic of wine names relating to the English-speaking world, and certainly none on Canadian wine names. There is material on wine names in the Rioja wine region of Spain (Pérez Hernández, 2013), and on Romanian wines (Siserman, 2013), which are self-evidently not about wine names in English-speaking regions. Setting aside commercially oriented catalogues, the vast bulk of literature on wine names is actually from the legal literature, relating to intellectual property or infringements on designation of geographical origin. The only works we can find relating to the English-speaking world are by Bertie Neethling $(2009,2013,2017)$, and we will refer to these below. Unsurprisingly, the internet has many lists relating to wine names, but with no analysis or history of the actual naming aspects. Thus, one can find lists of the following type: top-selling red wines in Canada, rude wine names, weird wine names, ${ }^{2}$ wines named after animals, wines with cool names, etc.

2 Even Canada's national newsmagazine, "Maclean's", has published a list of "Weirdly named Canadian wines and wineries", on August 24, 2012, https://www.macleans.ca/society/life/weirdly-named-canadian-wines-and-wineries/. 
In the Niagara region, some of the wineries named for the family name of founding owners are Colaneri Estate Winery ${ }^{3}$ (the vineyard was founded in 1967, but the winery with a large winery outlet store opened in 2010), Fielding Estate Winery (2007), Hernder Estate Winery (1993), Konzelmann Estate Winery (1984), Pillitteri Estate Winery (1993), Reif Estate Winery (1993), Malivoire Wines (1995), and Kacaba Wines (1999). The use of the word Estate in the winery name seems to signal that the winery uses grapes from its own vineyards and seems to have a substantial main building, often with a restaurant and a large tasting room. These wineries have maintained their names unchanged since their founding as they have an established reputation. Also, they have maintained for the most part the practice of only indicating on their label the grape name used for a particular wine. Colaneri indicates an Italian name for all of its wines on their web page; however, these names only appear faintly or not at all on their labels. Instead, the grape names appear prominently and there is a nice piece of art sketching on the various bottle labels (a design from a clever designer) which depict the characteristics of the Italian name. The names that seem to have appeared for the last dozen years or so and with the grape variety used for the particular wines are: Cavallone (Pinot Grigio); Coraggioso (Cabernet Sauvignon); Paese (Chardonnay); Mistera (Gewürztraminer); Pensieri (Merlot); Stellucha (Riesling); Unita (Cabernet Franc); Virtuoso (Pinot Noir) and Visione (Syrah). One notices that among the grape varieties Cabernet Franc has been grown in Ontario for some time and other grapes are relatively new arrivals, such as Gewürztraminer. The pictures on the labels are eye-catching and certainly make these wines stand out from other wines.

Reif Winery has joined the group of North American winemakers who are introducing the "Vin nouveau" tradition. Vin nouveau is a wine that is brought to market in the same year in which the grapes from which the wine is made were harvested. The most widely exported and available vin nouveau is the French Beaujolais Nouveau, which has made it a tradition since the 1980s to appear on the market worldwide on the third Thursday of November. Italy joined this market with their vino novello, with the Negrar Novello del Veneto most widely marketed wine, and Austria has had its Jungwein for a very long time. In the United States major wineries, such as Beringer, Fetzer, Sebastiani and J. Lohr have joined the "new wine" vogue, but also other areas of the United States that produce wine have now also joined in: Oregon (Bow and Arrow Division Wine Company) and New York State (the Finger Lakes' Keuka Lake Vineyards; Long Island's Macari Vineyards). Obviously, Reif Winery in Ontario saw that this marketing gimmick

${ }^{3}$ Most data in this article come from the various individual winery sites; a list would be too lengthy, and these are easily found by any interested reader. Occasionally the data come directly from wine-labels. Seldom has data-gathering for an article been this pleasurable. 
was successful and joined in. To make their wines stand out, Reif has resorted to Tarot card symbols. The Kerner (grape) Nouveau has the Hanging Man on its label, the Gamay (grape) Nouveau has the Fool and the Shiraz-Pinot blend has the Magician. A couple of other Ontario wineries have now also joined the vin nouveau craze: Chateau des Charmes has its Gamay Nouveau and the Pelee Island Winery (also from Ontario, but not from the Niagara region) has its Gamay Noir Nouveau.

Malivoire originally had very conservative labels, but over the last few years they have turned to designing their name with a superlarge " $\mathrm{M}$ " and bold letters for the rest of the name. They have also introduced new names for some of their wines: Guilty Men Red, Guilty Men White and Ladybug Rosé. These names on the labels are again in bold letters that can't be overlooked.

Until recently, the winemaker profession was exclusively a male occupation. However, now female winemakers have started to make their mark. One of them has achieved a high degree of name recognition and has named her winery after herself, using her full name: Sue-Ann Staff Estate Winery. Pearl-Morissette Estate Winery at first glance appears to be another winery named after a female winemaker, but it turns out that the name is a merging of the surnames of the two owners: Mel Pearl and François Morissette. There are also several well-known sports figures, TV personalities and actors who have started to produce wines. Among these are Wayne Gretzky, Mike Weir, Kevin O'Leary and Dan Aykroyd. These personalities use their full name on their labels, obviously with the intent that their names should contribute to the selling of their wines. These wineries usually started as virtual wineries, but have gradually grown into fully independent wineries. Wayne Gretzky even has another winery in British Columbia in the Okanagan valley. A virtual winery engages a winemaker, buys grapes from various vineyards and leases space in an established winery that has winemaking equipment.

Another group of winery names resort to naming their wineries after local landmarks, geographical features or road names. Among these are Mountain Road Wine Company, Peninsula Ridge, $13^{\text {th }}$ Street Winery, 16 Mile Cellar (2010), Between the Lines Wines, Back 10 Cellars (founded in 2002), Cattail Creek Estate Winery, Vineland Estates Winery (Vineland is the name of a town), Greenlane Winery (at the crossing of Greenlane and Cherry Avenue in Vineland) (founded in 2009); Rockway Glen Estate Winery (sounds more like a name for a golf course, and the place has indeed a large golf course as an attraction), Stoney Ridge WINERY (its original location was on Ridge Road in the village of Stoney Creek). Palatine Hills Estate Winery maintains the name of the original eighteenth century farm on whose land the winery is built. More unusual is the name Coyotes' Run Estate Winery, named after a road at the foot of the Niagara escarpment.

Alvento (exposed to the wind) and Vieni Estates Winery (come in, welcome) attest to their Italian owners/winemakers. Stratus was named after the clouds over 
the Niagara peninsula that made an impression on the owner. The winery label also shows pictures of clouds.

Chateau des Charmes and Pearl-Morissette wines indicate French-speaking winery owners, and the owner of Chateau des Charmes, Paul Michel Bosc, did arrive from France in 1963, after leaving Algeria in 1962. Chateau des Charmes was founded in 1978 and does not have a chateau; it only imitates the French fashion of naming wineries. It was the first winery that introduced "vitis vinifera" grape varieties to the Niagara region. "Vitis vinifera" refer to a group of standard European grape varieties. Chateau des Charmes still experiments with introducing grape varieties new to Canada and has recently introduced the Aligote grape, a rare variety from Burgundy, for the recent production of a white wine. François Morissette is a French-speaking Canadian who was trained in winemaking in Burgundy. His wines have French names: Le Spectateur (Cabernet Franc); Cuvée Dix-Neuvième (Chardonnay); Cuvée Mon Unique (Gamay); and Cuvée Métis (Cabernet Franc and Pinot Noir). The Métis People result from the mixing of the French immigrants to Canada in the $17^{\text {th }}$ and $18^{\text {th }}$ centuries with the Indigenous Canadian population. Cuvée Redfoot (Riesling) refers to the heavy red clay soil in which the Riesling vines are grown.

Angels Gate Winery recalls the fact that the winery is located on a property that was owned in the past by the Congregation of the Missionary Sisters of the Christian Church. This Ontario winery is housed in a building that resembles a typical California style mission.

Small Talk Winery is a 2009 renaming and rebranding of Stonechurch Winery. The wines have been given unusual names: Burning Ambition (Riesling and Gewürztraminer blend); Goodnight (Cabernet/Merlot blend) and Recap (Syrah). All three of their ice wines (made from the Riesling, Vidal and Cabernet Sauvignon grapes) carry the question "Dessert anyone?" underneath the winery and grape variety names on the label. All their wine bottles carry two labels, one on the front and one on the back, listing a jumble of a dozen or so small talk expressions. For instance, the three types of ice wine all carry the following labels, on the front: Look at you two; So in love!; Sweethearts all over again; You're just perfect together; Such happiness; Are you two always like this; So lucky to have found each other; and on the back label: If they smooch again, I'll gag; What on Earth!; Will this meal ever end?; They are so saccharine; Genuine flakes; So cloyingly ingratiating; Exaggerate much?; O puleeze get a room!. The white wine, Faux pas, made from a Riesling-Sauvignon Blanc blend, has the following phrases on the front label: Long time no see!; You look great; Nice outfit; You haven't changed a bit; Thanks for having us; I'd recognize you in an instant!; How is ol' what's his name?; Absolutely timeless; Have you lost weight?. For contrast, the back label has: Oh my!; I can 't believe I said that with a straight face; That's just 
not looking right sweetheart; Oh dear, is that really you?; Out of sight, out of mind; I've been avoiding you for so long; The years haven 't been kind; Someone had a bit too much sun; Meow, Meow!. Clearly, the intent is to amuse and if such wines are served at a gathering, they are bound to be a conversation piece. People will even forget to make remarks on the quality of the wine itself.

Organized Crime Winery clearly is also chosen to be an immediately memorable name. The name of the winery actually refers to a relatively tame incident. Two neighbouring Mennonite groups were feuding and one of them broke into the other's church, removed their organ and destroyed it. The names of the wines recall the event: Break-in (Pinot Noir); Pipedown (red blend); The Mischief (white blend); The Download (red blend).

Foreign Affair seems to call up a romance abroad, but it seems that this name only alludes to the family of the owner having taking a trip to Italy and having been impressed with the wines of Northern Italy, which induced them to try to copy those wine-making practices.

Megalomaniac Winery seems an odd and catchy name. On the winery's website, https://megalomaniacwine.com, the owner explains the name this way. "Originally I wanted to christen these wines with my name, John Howard, ...then my good friends accused me of being yet another '(profanity withheld) megalomaniac'. Regrettably, the name stuck". On the same web page, there is a link to an article in "Today's magazine", where John Howard, referring to the name Megalomaniac for the first vintage produced, explains the name this way: "I called it Megalomaniac frankly to poke fun at people in the wine business who take themselves too seriously". Both quotes shed light on the name's provenance. The theme is also transferred to some of the wines produced: Narcissist Riesling, Bravado Cabernet Sauvignon, Pompous (red blend), Big Mouth Merlot.

King's Court Estate Winery attempts to produce wines in the German tradition; the family (Zimmermann) also owns a vineyard in the Nahe wine-making region of Germany. The story is that in 1723 the "Emperor William, a German King" came to visit the vineyard in Germany and liked the wines. Hence the name for the winery in Canada. There is something wrong with this story, as in 1723 there was no German Emperor William and in 1723 there was no emperor who was also a king of Germany, as indeed there was no Germany. The emperor of the Holy Roman Empire at that time was Charles VI. In 1871, William, King of Prussia, became also emperor of Germany. Either the date or the name of the emperor is wrong - unless it is an entirely made-up story.

Featherstone Winery seems to be named after a family name, or else after some oddity of the terrain. But what is a featherstone? The name is, however, a contrived name, invented by the winery owners. They owned a gourmet food 
store that specialized in carrying poultry, from quail to turkey; hence the "feather". The property borders on the west on a rock face of the Niagara escarpment and to the rear of the property is a rock quarry, hence the "stone".

Leaning Post Winery seems an odd name to those not familiar with the practice of growing grapes. The vines are strung along wires which are held up by posts. The end post of such a row of posts and wires is a leaning post; as such, a post steadies the row. Thus, the vineyard name is taken from vineyard terminology.

Even though, as we have seen, there are now quite a number of wineries and wines that have names that could be termed unusual, most of them can be easily explained and do have a connection with the winery or the owners of a particular winery. However, some wineries have held on to conservative tradition, naming the winery after the family name of the owners and maintaining classic conservative labels that give the winery name, grape name, vintage, and sometimes the particular vineyard name. Most of the wineries that were founded in the early 1980's, such as Konzelmann and Peninsula Ridge, have maintained the conservative tradition, relying on their name alone to be the selling point. What would you rather pick off the shelf: a bottle of Burning Ambition from Small Talk Winery, or a bottle of Riesling, 2018, from the Konzelmann Estate Winery? In a very competitive market, this can be an important business question.

Besides the Niagara Peninsula, Ontario has several other smaller wine growing regions. All these have developed later than the Niagara region. Of particular note is the Coffin Ridge Boutique Winery, a two-hour drive north of Toronto, a hilly location at the very northern end of the Niagara Escarpment. The area is quite a bit colder than the Niagara region and special grapes had to be tried out to see if they would survive the climate. The winery made particular use of the coffin allusion in naming its wines: Back from the Dead Red; Into the Light White; Riesling Bone Dry; Resurrection Rosé.

British Columbia, the Okanagan valley in particular, has gone through a development similar to that of the Niagara region. Fruit farms, especially peach orchards, turned into grape growing vineyards. The development started a few years later than the Niagara region. One notices that wineries are rarely named after the family names of their owners. Instead they are to a great extent named after their location. However, whimsical names have also taken hold: Wild Goose Vineyard and Winery, Red Rooster Vineyard, Burrowing Owl Estate Winery, Black Widow Winery, Intrigue Wines, Misconduct Wine Co., Laughing Stock Vineyard, Blasted Church Vineyard, See Ya Later Ranch, Church and State Wines and Dirty Laundry Vineyard. The latter was named after a brothel at the same site about a hundred years ago. Wines from this winery all have names and their descriptions that have vague and not so vague sexual allusions: Kay-Syrah ("Que sera 
sera", "After a long, sensuous soak in French Oak, our sultry Kay-Syrah reveals herself as a pleasure to enjoy"); Secret Affair (white blend); Naughty Chardonnay ("This wine will remind you of Carmen Miranda, exotic, fruity and life of the party"); Not so Knotty ('naughty') Chardonnay; Dangerous Liaison ("In these tangled vines you're bound to find some pleasure. But was this scandalous tryst worth the risk. You decide".); Say yes (Pinot Gris, "let her caress your senses with fresh nectarines and a lively citrus finish").

The development in Canada of playful, witty, suggestive and humorous names for wineries and their wines seems to be unique, although a few of these types of name can be found in other English-speaking areas of the world (Australia, New Zealand, California and South Africa). They are not as pervasive as in the Niagara region of Canada. What one however finds in countries like the United States, New Zealand and Australia are wineries that resort to depicting animals, such as dogs, cats, lizards or penguins, on their labels, either with photographs or humorously sketched. Obviously the wineries rely on the animals' cuteness or humorous poses to catch the eye of a potential buyer. Wineries with such labels in the United States are Sleeping Dog Wines (Benton City, Washington State); Honeywood Winery (Salem, Oregon, producing Poodle Pinot Noir and Retriever Riesling).

In New Zealand, there is Huntaway Reserve with a sketch of a hunting dog on their label; and Cooper's Creek winery with their specialty wine group of Fat Cat Chardonnay and Tom Cat Merlot. Cooper's Creek also has a standard series, with writing on labels arranged in the usual order: wine name, region and grape name. Thus, we have: Little Rascal (Gisborne, Arneis), Guido in Velvet Pants (Huapai, Montepulciano), Bell Ringer (Gisborne, Albarino). These names may make you smile but they in general do not startle, unlike this winery's (Cooper's Creek) Cat's Pee on a Gooseberry Bush, the name given to an early harvested Sauvignon Blanc.

New Zealand wineries also make sure that the labels of all their wines resemble each other, and are thus easily distinguished from other New Zealand wines. At Oyster Bay Winery for instance, all eight of their wines have the same country scene on their labels. Ponga Winery has a fern on its labels: the Ponga tree fern. Starborough Winery has a starfish as a distinctive label. Bell and Gong Winery has a church bell, apparently to remind you of the bell and gong sounds that a ship makes when entering a bay to land. The owner of the vineyard was a professional mariner in his prior career.

Australia has about 60 wine regions and grows more than 100 different grape varieties. Of these varieties, the Shiraz grape is the most important (known elsewhere as Syrah). Australia has about 2,360 wineries, with South Australia having the largest number of wineries in the country, about 960 wineries. One of the 
best known wine-growing areas in South Australia is the Barossa Valley. It now has over 19 wineries. Here many German immigrants settled in the $19^{\text {th }}$ century and many of them brought wine-making knowledge with them. Their German gradually developed into a new dialect known as Barossa-Deutsch, a blend of English and German. One can see the German influence reflected in the names of the present wineries in the area: Peter Lehmann, Dutschke Wines, Rolf Binder, David Franz, Schild Estate, Teusner, Henschke and others. The Langmeil Winery in the Barossa area offers a wine called Hangin'Snakes. It is explained by the story of a grower on the Langmeil Winery estate, Wally Krieg, who muttered "Hangin' snakes" when the heat and work started to become too much for him.

South Australia had the Little Penguin Winery, with a small sketch of a penguin on its wine labels. This winery was bought by a large California winery, Bronco Wines, and its main production, was shifted from Australia to the United States, with grapes sourced from various locations. Its sales have gone down greatly. Little penguins don't sell as well in the USA.

Treasury Wines is one of the world's largest wine companies. It has a large stake in wineries in Australia, holding companies such as Penfolds, Wolf Blass and Lindeman's. It also owns the 19 Crimes Winery. The nineteen crimes refer to the number of crimes for which people could be deported from England to Australia. This 19 Crimes Winery has remarkable labels, depicting Australia's history as a country where Great Britain deported its criminals in the $18^{\text {th }}$ and $19^{\text {th }}$ century. The wine drinker is informed about Australia's history and the minor offences for which these people were convicted. Practically all these convicts stayed in Australia after their release and they formed a large portion of Australia's early settlers. The wine buyer can drink wine and learn about Australia's history from the labels.

Leading in inventiveness for its wine names is the small family-owned Hesketh Wine Company, based in the Barossa Valley. Here we have Thirsty Dog, a Cabernet Sauvignon wine, Resurrection, from the Shiraz grape; Midday Somewhere, also from the Shiraz grape; and two wines named for imaginary animals: the Shiraz Vulturedog (a dog with wings) and from a Pinot Noir-Shiraz grape mixture the Porcupotamus wine (a hippopotamus and porcupine mixture, with five feet long quills). All wines have interesting sketches or pictures on their labels.

An area of Australia that is easily overlooked as a wine-producing region is the island of Tasmania. One interesting name for a winery there is Every Man and his Dog vineyard. The label has a sketch of a black dog looking at a bunch of grapes. Apparently, the owner had the idea for the name because his dog always came with him when he went to work in the vineyard. His wife may have had a similar experience, because there are also wines named Every Woman and her Dog. 
South Africa, another country where English is widely spoken, but a multilingual context does introduce some complexities (see Neethling, 2009, 2013), produces well known wines, exported worldwide. Here the names of the wineries are for the most part the name of the owner (see also Neethling, 2017), but the names of particular wines show some imagination. Warwick Winery's labels have: grape variety, area of production and a particular name such as The First Lady, Sauvignon Blanc, The Blue Lady Cabernet Sauvignon, Chardonnay, The White Lady Chardonnay; Three Cape Ladies Cape Blend. Neethling (2017, p. 75) also cites Val du Charron Wines' "Girlfriends Wines" series, pitched to a youthful market: Classy Girl, Good Girl, Crazy Girl, Romantic Girl, Wild Girl, Party Girl.

Fairview Estate Winery produces and sells the largest number of South African Wines. It is located in the Western Cape Area, at the foot of the Paarl Mountains. What is noteworthy about this winery are the 1,000 goats on the estate. The estate produces cheese, as well as wine. This winery has several groups of wine, each group with a different name. All groups have both red and white wines: $L a$ Capra, an obvious name, given the goats on the vineyard, Goat Roti, Bloemcool (eye-catching, as a wine named cauliflower, but the earlier name of the Fairview Estate was Bloemkoolfontein). The most widely recognized name of this winery and its best seller is Goats do Roam. This group features lower priced white and red blend wines, as well as rosés. These wines were apparently inspired by the wines of the French Rhône valley. One can gather a similarity of sounds between Côtes du Rhône and Goats do Roam.

What does this brief discussion show about wines, wine names and winery names? Enjoying wines lies not only in the drinking, but also in the buying and spending time in wine stores reading labels, reading the names, smiling at some, and being informed about history or landscapes by others. One can be amazed at the variety of grape varieties and areas where wine is now grown. As pointed out, Canada is a relative latecomer to the wine industry, but it has found a niche in the industry. Even though Canada doesn't seem to have gone the way of relying on cuteness on its wine labels, but rather on startling and playful naming, the effect that most wineries in the English-speaking world seem to wish to achieve is still the same - to catch the eye of the customer in a crowded market. However, do these types of names for wineries and wines really convince people to buy wines? We are not sure, but they certainly make people stop, pick up a bottle, read the label and smile. Unusual and eye-catching names for wines and wineries have become a pervasive occurrence throughout the English-speaking world, with Canada somewhat of a leader, followed closely by Australia and the West Coast of the United States, and less so in New Zealand and South Africa. This trend has taken hold and it seems now here to stay. 


\section{REFERENCES}

Ainiala, T. (2020). Aspects of localness: A pilot study of kiosk and grill food names in Finland. Onomastica, 64, 167-177.

Neethling, B. (2009). Names as a vehicle towards transformation in the South African wine industry in People, Products, and Professions. In E. Lavris, \& F. Fischer et al. (Eds.), Choosing a Name, Choosing a Language (pp. 279-287). Frankfurt am Main: Peter Lang.

Neethling, B. (2013). Innovation and creativity in the coinage of new names for South African wine: a few case studies. In O. Felecan, \& A. Bugheşiu (Eds.), Onomastics in Contemporary Public Space (pp. 240-256). Newcastle upon Tyne: Cambridge Scholars Press.

Neethling, B. (2017). The role of anthroponymic commemoration on wine labels in South Africa. Names, 65(2), 65-77.

Pérez Hernández, L. (2013). A pragmatic-cognitive approach to brand names: a case study of Rioja wine brands. Names, 61(1), 33-46.

Siserman, M.M. (2013). Nume de vinuri şi de soiuri de struguri româneşti [Names of Romanian wines and grape varieties]. In O. Felecan (Ed.), Name and Naming. Onomastics in Contemporary Public Space (pp. 157-169). Cluj-Napoca: Mega/Argonaut.

\section{SUMMARY}

Over the last fifty years, the number of wineries in the English-speaking world has rapidly grown and with it the number of wines available has also increased. We are referring particularly to Canada, the United States, Australia, New Zealand and South Africa. With the increase in the number of wineries and wines has come an attempt by wineries to differentiate themselves by their names and the names of their wines. We discover that the names chosen mainly rely on regional history and culture as well as on humour. We take the Niagara region in Ontario, Canada, as our main example for systematic analysis, and then make reference to other English-speaking wine-producing ${ }^{4}$ regions in Canada (British Columbia), Australia, New Zealand, South Africa and the west coast of the United States (California, Washington State and Oregon).

${ }^{4}$ Obviously, there are very many English-speaking countries beyond those we mention in this paper, but almost all produce either no or very little wine, and none for export. Also, in this article, we use "wine" to mean exclusively wine produced from grapes, and not wine produced from berries, fruits, flowers, herbs, spices, etc. 